\title{
JUDICIAL INDEPENDENCE VIS-À-VIS JUDICIAL POPULISM: THE CASE OF ULAYAT RIGHTS AND EDUCATIONAL RIGHTS
}

\author{
Rosa Ristawati* \\ Faculty of Law, Airlangga University, Surabaya, Indonesia \\ rosa@fh.unair.ac.id \\ Radian Salman ${ }^{* *}$ \\ Faculty of Law, Airlangga University, Surabaya, Indonesia \\ radian.salman@fh.unair.ac.id
}

Received: 5 June 2019 | Revised: 25 February 2020 | Accepted: 8 April 2020

\begin{abstract}
Judicial populism may occur when judicial branches are much more influenced by the interest of people majority. In this context, it is when justices deliver decisions according to what the people wanted and not what it has to be decided by laws. The Constitutional Court of the Republic of Indonesia (MKRI) has the pivotal role to protect the Constitution, democracy, and the rule of law principles by adhering judicial independence in the decision making process. This paper aims to briefly find out whether the MKRI decisions on the particular issue of economic and social rights show the tendency of judicial populism and defending judicial independence. A brief conclusion would be drawn from the analysis of the two MKRI's landmark decisions on the relevant issues of economic and social rights, in particular issues of Ulayat rights and educational rights (Case Number 35/PUU-X/2012 on the judicial review of Law No. 41 of 1999 on the Forest and Case Number No. 13/PUU-VII/2008 on the judicial review of Law No. 16 of 2008 on the Amendment of the Law No. 45/2007 on the State Budget). In a short analysis of both landmark decisions, the MKRI tends to defend its independence in delivering its decision. The Court also shows its consistency in protecting the Constitution by strictly upholding the constitutional values laid down in the Constitution and against the judicial populism. The Court in both

Lecturer at the Faculty of Law, Airlangga University. Holds a Ph.D. in Constitutional Law from Maastricht University, The Netherlands.

** Lecturer at the Faculty of Law, Airlangga University. Holds a Ph.D. in Constitutional Law from Maastricht University, The Netherlands.
\end{abstract}


decisions shows its constitutional commitment to preserving democratic values of minority-marginalized protection against the dominant-majoritarian interest. In the particular issue of education rights, the Court hinders the fulfilment of educational rights from the elite interest by preserving the constitutional purpose of making priority $20 \%$ for the education budget. In general, the MKRI has to guard preventing the Constitution and the rule of law principles, specifically on the issue of the protection of economic-social rights. It upholds judicial independence and put asides judicial populism.

Keywords: Constitutional Court, Economic-Social Rights, Judicial Populism, Judicial Independence, Majoritarian.

\section{INTRODUCTION}

The word populism was from the Latin word populous, which has the meaning of "people". ${ }^{1}$ In practice, populism does not always connect to the political authority which attaches to the executive branch or the legislative branch but also may come into existence to the judiciary branch on particular decisions. In this context, the Court delivers decision on behalf of the people will and decides not according to the majority in favor. This article aims to find out whether the Constitutional Court of Indonesia (MKRI) could consistently defend its independency and survive in dealing with the phenomena of judicial populism, a phenomena where the judiciary branch is interfered with by the will of the majoritarian people. This article is specifically addressed to look how the Constitution is being uphold in particular issues of the protection of rights of social and economic rights, which in this article are represented by the Ulayat rights and the educational rights. The argument in this article is started with a brief of description of the emergence of populism in Indonesia. However, it will specifically be addressed to look how the populism influences the Court decision and how the Court could survive its independence. This article aims to address specific cases which relevant to the social, economic rights by analyzing the Court's decisions on such issues. It ends up with the issue on how the judicial populism may interrupt the principle of judicial independence.

Matthijs Rooduijn, "A Populist Zeitgeist?: The Impact of Populism on Parties, Media and the Public in Western Europe" (Dissertation, University van Amsterdam, 2013), 6. 
The Constitutional Court has the pivotal role to protect social and economic rights in Indonesia. The role may be reinforced through constitutional restraints against any violation of social economic rights in Indonesia. Indonesia as a democratic and rule of law state has strong values of constitutional democracy that could hinder from the negative manifestation of populism. The Court may overlay with the dilemma of being counter-majoritarian where in one side delivering a justified-reasoning of judgment, the Judges may vis a vis to the populism and stand against the majority of people will. Against the populism, the Court shall be an intermediate institution bridging the rule of law and people demand. As an intermediate institution, the Court may become counterpart institution when the legislative or executive become populist. To be an intermediate institution, the Court shall act as its nature, applying the law and holding the ground of constitutionalism and legalism. To protect social, economic rights, the Court has to uphold the core values of legitimacy, judicial objectivity and act according to its basic mandate to adjudicate disputes even when it has to contradict with the will of people majority in order to protect the minority interest. In this context, against judicial populism, the Court's decision has to combine wellreasoned judgment, and an ironclad will resist the sometimes violent force of public opinion. ${ }^{2}$ According to the shared values approach, a judge's duty is to adjudicate disputes by giving effect to underlying principles even if this means acting contrary to public sentiment. In all situations, but especially in the face of surging political populism, judges must recall and fulfill this basic mandate. Ironically where the legislature becomes populist, courts have an obligation to compensate for this democratic deficit and actively defend the societal shared values. This additional responsibility, however, may trigger judicial populism. In order to avoid this phenomenon, Court (like integrative representatives in the political sphere) must remain vigilant, shield their decisions from fleeting changes to the public mood and draw on society's fundamental core of shared values. ${ }^{3}$

This paper would try to analyze how the issue of judicial populism may influence the independence of the Indonesian Constitutional Court. An

Alon Harel, "Courts in a Populist World," VerfBlog, 27 April 2017, 4.

Harel, "Courts in a." 5. 
inclination to favor judicial independence is fundamental to ensure that all people are securely governed by the Rule of Law. In analyzing the issue, this paper attempts to analyze two Constitutional Court landmark decisions, namely: Case Number 35/PUU-X/2012, reviewing Law No. 41 of 1999 on the Forest and the Case Number No. 13/PUU-VII/2008, reviewing Law No. 16 of 2008 on the Amendment of the Law No. 45/2007 on the State Budget 2008 (the APBN). Both Court's landmark decisions are in particular cases of the Court's Decision, which influence the state fulfillment on the economic and social rights. Both are expected to represent the landmark of the Court's Decision on economic and social rights in the field of education rights and water rights. In the end, it is expected to give a preliminary hypothesis on the tendency of whether or not the judicial populism is undermining judicial independence.

\section{POPULISM AND THE JUDICIAL POPULISM}

Populism may emerge coincide with democracy. According to Rousseau, democracy is a form of government which the sovereign may put the government in the hands of the whole people or of a majority of them. ${ }^{4}$ In this context, populism may arise when the majority in a democracy is being dominant, and the minority is being neglected. Democracy gives opportunity to the rise of populism in a way that democracy gives privilege and priority to the interest of the people majority. The debate over populism movement actually has been started as the concept of the state in Ancient Greek history developed. Plato concerned that as well as oligarchy, democracy is the same having the potential of excessiveness which caused opposite direction reaction. ${ }^{5}$ Furthermore, Plato determined that the people are the third class who are not politician but being the largest and the most powerful class in a democracy. ${ }^{6}$ This may be the root of how populism is being arise in the modern day. On the other hand, Polybius, who was famous for the "cycle of Polybius," came up with the theory that democratic government might transform into a bad shape of government since it is naturally generating

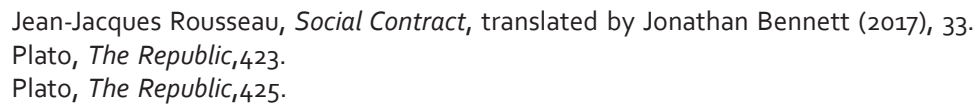


vice inseparable such as in democracy lawless ferocity and violence. ${ }^{7}$ The concern on bad government when everything on the people majority will would also an issue of undermining minorities will. In politics, populism is known as politics conducted through a relatively direct relationship between a charismatic leader and the people. ${ }^{8}$ This is in line with the argument of Cas Mudde who argued that populism is about the elite and the people. ${ }^{9}$

On the other arguments, populism is democratic in a sense that common people are trustworthy and competent-given a chance to make wise choices. ${ }^{10}$ Populism is a movement of against the established authority, against both the private and government sector and distrusted the elites who has the power." There is a difference between populism and progressivism. While progressivism is in the tone of moralistic with the intention of reforming government and society, populism distrusts representative government and seek to constrain it. ${ }^{12}$ In general, the populist and the progressives initiate the process in different objectives. The progressives have intention to serve as an additional check on representative government in order to improve the quality and effective government, whereas the populist intends to have a radical vision in order to undermine the representative government by shifting power to the people. ${ }^{13}$ In general, progressivism recognizes the legitimation of representative government but requiring better progress for society. It demands changes that fit with the development and global changing in the community.

In general term, populism may be a threat for democratic principles in ways that it may be a parasite to the ecosystem of constitutional democracy. ${ }^{14}$ Populism

7 Polybius, The History of Polybius Book Six, in Parentheses Publication Greek Serie, trans. Evelyn S. Shuckburgh (Cambridge, Ontario, 2012), 355.

8 Olle Törnquist, "Stagnation or Transformation in Indonesia," Economic and Political Weekly XIIX, no. 50 (13 December 2014): $23-27$.

9 Cas Mudde, "The Populist Zeitgeist," Government and Opposition 39, no.3 (2014): 541 - 563.

10 Abubakar Eby Hara, "Populism in Indonesia and its Threats to Democracy," Advances in Social Science, Education and Humanities Research (ASSEHR) 129 (2018): 106.

11 Abubakar, "Populism in Indonesia," 106. In this definition, see also, Ehito Kimura, "Populist Politic in Indonesia," (Asia Pacific Bulletin, East- West Center no. 407, 7 December 2007).

12 Abubakar, "Populism in Indonesia," 107.

13 Kenneth P. Miller, "Constraining Populism: The Real Challenge of Initiative Reform," 41 Santa Clara Law Revie 1037 (2001).

14 Théo Fournier, "From Rhetoric to Action - A Constitutional Analysis of Populism" (EUI Working Paper LAW 2018/08, European University Institute, Italy, 2017) : 4. 
may manipulate constitutional democracy principles through the populist rhetoric of majority manipulation, by creating a unitary and uncompromising majority and the manipulation of the rule-of-law principles. ${ }^{15}$ The manipulation of majority as unitary and homogenous is that because the majority is assumed to be undivided or undifferentiated. Still, such an assumption is a fiction considering that the majority in a democracy is an accumulation of different minority expectations. ${ }^{16}$ Furthermore, the constitutional structure with the check and balances and the human rights framework would become slower and fierce because populists gradually would change regulations; for example, values such as political pluralism, transnational solidarity, and protection of minorities would render incompatible with populism interest. ${ }^{17}$ In this context, the Constitutional Court may have the role of an institution by integrating a proper and firm legal framework into its judicial decision and protecting democratic values from negative tendencies in order to strengthen the foundation of democracy.

In Indonesia, populism is the peril of the representative democracy system where restricted elites in bureaucracy and the oligarchic system emerge within the system. To this extent, people realize that the representative government does not represent the interest of the people. The process of government is merely reflecting the interest of particular groups such as political parties in the political system. To this extent, the populism movement proclaims for defending the neglected group. The issue of populism is actually not being significant in the whole political system in Indonesia. It is because the movement is not quite often and not that tangible controlling the political system in Indonesia. ${ }^{18}$ But the indication and the potential movement of populism has been shown by several political parties, mass organization, as well as an individual. In a political situation, the Court may be an object of political populism. However, in a different situation, the Court may show its tendency of populism and become

\footnotetext{
${ }^{25}$ Théo Fournier, "From Rhetoric to," 3.

16 Théo Fournier, "From Rhetoric to," 5.

7 Théo Fournier, "From Rhetoric to," 6.

18 Bala Raju Nikku and Azlinda Azman, "Populism in the Asia: What role for Asian Social Work?" Social Dialogue Issue, September 17, 2017, https://socialdialogue.online/SDpdf/VOL.17.pdf.
} 
populist Court when it put forward the people will suppress the minority interest while putting aside the judicial independence and impartiality. To this extent, judicial populism may emerge. There are several aspects that may indicate the rise of judicial populism. One of the aspect is that when the Court's decision is decided not according to majority in favor but merely that the decision is based on the pressure of the people majority's interest. In this context, the judges may wrongly interpret the Constitution. Judicial populism has to be differentiated from what is called by judicial activism. A populist judge adheres a more aggressive form of judicial activism when a judge makes priority for not only policy over precedent but also over the process. ${ }^{19}$ A populist judge would be instead of seeking legitimacy by framing his role as championing the majority of people will against that undermine that will. ${ }^{20}$ To this extent, judicial populism may be shown from how the judge tends to speak for the people or when the Court delivers decision adjusted and influenced by the majority of the people will while it is actually beyond justice, impartiality, and judicial independence. However, the Court could oppose the people majority will by inserting the resistance of populism in its judicial decision on the basis of legalism and the core values. ${ }^{21}$ This is what we commonly known as counter-majoritarian role of the Court. It is when the Court is trying to defend judicial independence as well as safeguarding democratic values by, for example protecting the minority. In such way, the judicial populism has the tendency of being in opposite purpose with the values of the rule of law. It may be undermined the judicial independence as one of the essential judiciary principle.

With regards to judicial populism, we may refer to the Colombian Constitutional Court. The Court might have an extreme experience when facing challenge as its nature (as an independent institution) under the populist leader regime. The Colombian Constitutional Court played its role as an intermediate leading the consolidation of a rival political project conducting a forum to discuss

\footnotetext{
19 Yasser Kureshi, "What is Judicial Populism and how does it Work in Pakistan?" www.dawn.com/news/1461194/ what-is-judicial-populism-and-how-does-it-work-in-pakistan.

20 Kureshi, "What is?"

${ }^{21}$ Alon Harel, "Courts in a Populist World," VerfBlog, 27 April 2017, https://dx.doi.org/10.17176/20170428-104853.
} 
problems and design public policy setting back public policy for the internally displace people rights by the incumbent government. ${ }^{22}$ In this context, the Court has its own political project with wide public support, including the agenda of judicial protection of social and economic rights, which made visible individual and groups traditionally neglected. ${ }^{23}$

\section{JUDICIAL POPULISM AS A THREAT TO JUDICIAL INDEPENDENCE}

The Constitutional Court is one of the judiciary branches which the power is separated from the other two branches. As an independent branch, the Court has judicial independence, which gives the Court institutionally independence from any kind of intervention while performing its judiciary power. In Indonesia, the MKRI is one of the Court holding judiciary power. As the nature of the Court, the Constitution provides the guarantee of its independence on Article 24 Section (1) of the Constitution, which declared that the judicial power is independent in performing its judicial process to uphold law and justice. ${ }^{24}$ According to the Basic Principles on the Independence of the Judiciary, the principles of judiciary independence are including as follows:

"1. The independence of the judiciary shall be guaranteed by the State and enshrined in the Constitution or the law of the country. It is the duty of all governmental and other institutions to respect and observe the independence of the judiciary.

2. The judiciary shall decide matters before them impartially, on the basis of facts and in accordance with the law, without any restrictions, improper influences, inducements, pressures, threats or interferences, direct or indirect, from any quarter or for any reason.

3. The judiciary shall have jurisdiction over all issues of a judicial nature and shall have exclusive authority to decide whether an issue submitted for its decision is within its competence as defined by law.

4. There shall not be any inappropriate or unwarranted interference with the judicial process, nor shall judicial decisions by the courts be subject to revision. This principle is without prejudice to judicial review or to

\footnotetext{
22 Jorge Gonzales-Jacome, "In Defense of Judicial Populism: lessons from Colombia," Int'l J. Const. L, ( 3 May 2017).

23 Jacome, "In Defense of."

24 Indonesian Constitution. Art. 24 (1).
} 
mitigation or commutation by competent authorities of sentences imposed by the judiciary, in accordance with the law." 25

According to Article 3 (1) of Law No. 48 of 2009, the judiciary independence in Indonesia is defined in more specific for the judges in doing their duties and functions. It is stipulated that judges and the constitutional judges shall preserve the judiciary independence. Section (2) of the Article specifies that any interventions from any other parties against the court's affairs are prohibited, instead of according to the Constitution. Furthermore, the explanation of Article 3 Section (1) determines that the judiciary independence has the meaning that the Court is free from any interventions and free from any kind of physical and psychological intimidation. In this context, it is in line with the general term of judicial independence according to Arjana Llano which argues that the judiciary independence consist of two aspects namely:

"The first relates to the way judges are kept in safe from the improper influence of third parties (individuals or institutions). Whereas, the second related to the extent judges think, act, and decide independently of certain factors other than actual and lawful ones. The first factor refers either to the legal system or practically to the judicial system, whereas the second factor refers more to the opinion of the judges." ${ }^{26}$

To this extend, the judiciary independence leaves loopholes to the rise of judicial populism in particular when judges decide not according to the justice and legal certainty, but according to what the people want. In this context, judges are driven by the majority of the people will and not decide as what it has to be decide and even decide beyond the laws. In practice, the judicial independence grants judges the freedom to think, freedom of action, and freedom to decide. However, it does not mean that judges could be beyond the laws. The judges have to be in accordance to the Laws and has judiciary obligation to do legal finding. They has to do legal finding activity on the basis of social justice and legal certainty. Article 5 (1) the Law on Judiciary Power stipulates that the

25 Basic Principles on the Independence of the Judiciary Adopted by the Seventh United Nations Congress on the Prevention of Crime and the Treatment of Offenders held at Milan from 26 August to 6 September 1985 and endorsed by General Assembly resolutions 40/32 of 29 November 1985 and 40/146 of 13 December 1985

26 Arjana Llano, "Independence of the Judiciary," Juridical Tribune 3, no. 2 (December 2013): 109 - 115. 
judges and the constitutional judges has to find, apply, and understand the legal values and social justice within the community. In particular, in such way, the MKRI exceedingly also has a special challenge in guarding the Constitution and protecting its values. This may give the Court high-pressure and more challenge while protecting the Constitution as its main duty, the Court is intimidated by the people will. To this extent, the Court has put forward the judiciary independence and put aside the majority of people will. The judges have to be independent in the decision making and decide according to the Law and justice in protecting the Constitution.

Judicial independence and impartiality of the judiciary, legal certainty, nondiscrimination, equality before the law, and respect for human rights are the essential rule of law principles. Those rule of law principles shall be applied alongside with the principle of democracy. The rule of law principles are essential for the implementation of democracy as well as providing protection of democratic values within political system. On the other hand, the Court provides restoration and improvement of community security that will prevent democracy against any negatives excess of populism. It has the role to bridge the societies dealing with the legacy and conflict, as well as providing the foundations for building inclusive, well-governed societies and political peace stability. As one of the institutions holding the judiciary power, the Constitutional Court is the vanguard institution to make effective the laws in the corridor of the rule of law framework ${ }^{27}$. In the judicial process, the Court has to ensure that the Constitution is put forwarded among other things. It is mainly because the Constitution strongholds the basic constitutional rules and the demand of particular majorities while it secures the Court's independence in particular the Constitutional Court and Supreme Court in interpreting the Constitution and the Laws, and sets up and protects the standards framework of rule of law. ${ }^{28}$

\footnotetext{
27 Pratikno and Cornelis Lay, "From Populism to Democratic Polity: Problems and Challenges in Surakarta, Indonesia,", PCD Journal III , no. 1-2 (2011) : $33-62$.

28 Neil Walker, "Populism and Constitutional Tension" (Monnet Working Paper 15/17, Symposium: Public Law and The New Populism, 2013). Accessed online at: www.JeanMonnetProgram.org : Neil Walker defines "In functional terms, a constitution typically involves a 'triple lock' control of the political system. The first and most fundamental lock involves the entrenchment of the basic constitutional rules of the game against amendment or replacement, or at least a requirement of special majorities. The second lock concerns the independence of the constitutional court or other apex courts in interpreting the constitution and the laws made under it. The
} 
To this extent, the Indonesian Constitution has provided the design of the Constitution which in general has accommodated values on the pluralism and minority safeguard. Under the Indonesian Constitution, democracy is living coexistence with the rule of law under Article 1 of the Indonesian Constitution. Democracy, as it is stipulated in Article 1 (2) of the Indonesian Constitution (the Amendment) confirms that the Constitution ensures that the sovereignty is in the hands of the people and is implemented according to the Constitution. The Article emphasizes that democracy in Indonesia is constitutional democracy as well as giving strong commitment to the protection of democracy by giving the sovereignty to the people but all the implementation has to be in accordance to the Constitution, thus the Laws. The Constitution also ensures that the rule of law is adopted and that, it provides constitutional basis for any conflict resolutions have to be resolved in accordance to the law.

The principle of judicial independence and impartiality has to be reflected in the judicial activities of the Constitutional Court. The Constitutional Judges have to decide independently. However, they have to really make sure that the decision is not only for the interest of particular groups but for the interest of the entire people, including the minorities. In the decision making process, the judges have to confirm that the constitution is protected as well as making sure that the provisions of the Constitution are interpreted as what it has to be. Therefore, the Court decisions provide constitutionality guarantee and preclude from judicial populism, which may disrupt the independency of judicial.

\section{JUDICIAL POPULISM, THE EDUCATIONAL RIGHTS, AND THE ULAYAT RIGHTS}

This section will be a brief and preliminary analysis of whether the MKRI's decision which relevant to the issue of judicial populism. The analysis will be drawn from the two of MKRI's landmark decisions on the issue of economic and social rights, in particular the Ulayat rights and rights to education. The analysis

third lock involves the basic 'rule of law' requirement that government be conducted according to laws that have been duly passed under the widely-endorsed foundational constitutional pact and interpreted by a judiciary insulated from executive or other partial interference". 
is focused on the Court's consideration for analyzing the Court legal reasoning and the basis of the Court Decisions. The analysis would be drawn to find the Court's experience on avoiding judicial populism while defending the judicial independence and protecting the Constitution. As one of the Court's competence to conduct a judicial review on the constitutionality of the Laws, the Court has to show its consistency to preserve its nature as an independent institution. The Court has to decide what has to be decided and put forward the Constitution by referring to the constitutional values laid down in the Constitutional provisions. The commitment is essential to prevent judicial populism where judges speak on the basis of interest of majority people rather than speak as what the Constitution intended on the basis of justice and constitutional certainty.

The protection of economic and social rights is being an essential in the area of constitutional protection and adjudication under the area of the constitutional duty. The scope of economic and social rights may be broad. The economic rights are commonly including the right to use, posses, exchange, dispose property and even including rights to get economic interest and benefit. ${ }^{29}$ On the other hand, social rights are defined as rights to food, housing, health care, and social security. ${ }^{30}$ David Landau argues that much of social rights has to do with the majoritarian and benefits to the middle and upper class while there is a strong relationship between the remedy model by the court and the identity of the beneficiaries from the intervention. ${ }^{31}$ In the context of judicial populism, the Constitutional Court has to come up with the decision of conforming marginalized or minority interest in order to protect democracy and uphold the Constitution and the rule of law. Both landmark Court's decisions may show that in a struggle to defending judicial independence, the court is avoiding being populist.

In the Case Number No.35/PUU-X/2012 on the Judicial Review of the Law No. 41 of 1999 concerning on Forestry, the Court reviewed the constitutionality of Article 1 Paragraph (6), Article 4 Paragraph (3), Article 5 Paragraph (1),

\footnotetext{
29 Terence Daintith, "The Constitutional Protection of Economic Rights," I.CON 2, no. 1 (2004): 56-90.

30 David Landau, "The Reality of Social Rights Enforcement," Harvard International Law Journal 53, no. 1 (2012): 190-246.

${ }^{31}$ Landau, "The Reality of," 202.
} 
Paragraph (2), Paragraph (3), and Paragraph (4), as well as Article 67 Paragraph (1), Paragraph (2), and Paragraph (3) the Law No. 41 of 1999 on Forestry against Article 1 Paragraph (3), Article 18B Paragraph (2), Article 28C Paragraph (1), Article 28D Paragraph (1), Article 28G Paragraph (1), Article 28I Paragraph (3), and Article 33 Paragraph (3) the UUD NRI 1945. The petitioners in the judicial review claimed that their traditional forest territories as part of their ulayat rights were disappeared so that they did not get access to get benefit managing their traditional forest, and so, they did not get access to work and income sources. The Court justified that the fundamental aspect is that the Constitution recognizes and respects the ethnic indigenous community as the entity and, therefore, shall have rights and obligations. To this extent, the ethnic indigenous community is the legal subject and that, may not be ignored in particular when the Law regulates the allocation of natural resources. Moreover, the Court assumed that the UUD 1945 has already provided the Constitutional basis as it is mentioned in Article 33 Section (2) 32 $^{2}$, Section (3)33, and Section (4) of the UUD 1945 $5^{34}$. In this Court's Decision, the Court implies that the ownership and occupancy of the natural resources by the state is for the entire people including the ethnic indigenous people since there is a fundamental aspects of indigenous rights in the exploitation of natural resources. In this context, the Court would like to protect democratic values in terms of protecting the minority as well as put aside the elite government interest and populist interest. The Court refers to not only people as the member of customary legal community but also people as an individual. In fact, in reality was different since there was different treatment. In that such different treatment, the ethnic indigenous community is potentially losing their rights in particular their traditional ulayat rights. This situation gives difficulties to the ethnic indigenous people to fulfill their daily needs. The people

32 Indonesian Constitution of 1945. Art 33(2). "Sectors of production which are important for the country and affect the life of the people shall be under the powers of the State".

33 Indonesian Constitution of 1945. Art 33(2). "The land, the waters and the natural resources within shall be under the powers of the State and shall be used to the greatest benefit of the people".

34 Indonesian Constitution of 1945. Art 33(4). "The organisation of the national economy shall be conducted on the basis of economic democracy upholding the principles of togetherness, efficiency with justice, continuity, environmental perspective, self-sufficiency, and keeping a balance in the progress and unity of the national economy". 
are getting difficult to get access to gain benefit from the forest as the natural resources. The ethnic indigenous people are mostly as the victim against the domination of the elite government and majority of people who have interest in the natural resources. As the victim, they are weak against the state, elite government, and the majority groups who has the strong ownership. The Court in its Decision had made a clear standing that the unfair, in justice, and the ignorance of the ethnic indigenous people as minority community is caused by the regulation, which partially tends to give benefit to the elite government and majority people. The Court's Decision reflects that the consideration has to be in accordance with the principle of justice and constitutional-democracy, and that any situation which puts minority (ethnic-indigenous community) inferior against the elite and majority domination is unconstitutional and against the constitutional values. In this context, the Court shows the tendency of against populism where minority interest is undermined by majority interest.

Furthermore, the Court affirms that the constitutional values which recognizes the ethnic-indigenous community have a consequence that the community has the right to get benefit from the indigenous forest as well as getting their Ulayat rights (the Land-indigenous rights). The Court said that it is also as a consequence of the customary indigenous law as living law. The Court refers to the legal history in Indonesia, which had recognized the ethnic-indigenous people since the period of Colonial Netherlands. In this context, the Court emphasizes that the recognition of the ethnic indigenous community after the Amendment of the Constitution is based on Article 18B Paragraph (2), as well as according to the legal basis of the Law No. 39 of 1999 on the Human Rights; Law No 32/ 2004 on the Local Government; Law No 31 of 2004 on the Fishery; and Law No 27 of 2007 on the Management of the Coastal Territory and Small Islands. This argument is also in line with the Court Decision on Case Number 3/PUU$\mathrm{VIII} / 2010$ in which the Court gave recognition to the ethnic-indigenous people with the consideration of Article 33 Paragraph (3) UUD 1945. In such previous Decision, the Court affirmed that the exploration of the natural resources for the prosperity of the people has to be considered as a right not only as individual 
rights which had been existed but also as the collective rights which belongs to the ethnic-indigenous community (the Ulayat rights), as the ethnic-indigenous community right as well as other constitutional rights which have been attached to the community and have been guaranteed by the Constitution, for example, the rights to pass and the right to access healthy environment. In this context, the Court consistently supports the protection of democratic values by respecting the ethnic minority community as well as its ethnic customary law.

Moreover, the Court also refers to Article 1 paragraph 4, the Forestry Law, which provides the legal basis to avoid overlapping of authority between the state authority and the ethnic indigenous authority in terms of forest. The Court was consistently stick to Article 18B paragraph (2) and Article 28I paragraph (3) the UUD NRI 1945 determining that the recognition and protection of indigenous forest is integrated with the Ulayat rights (the indigenous-land rights) of ethnicindigenous rights. This is not because the majority will of the people interest but rather because the consequence of the recognition of indigenous law as the living law in Indonesia. Therefore, the state policy on classifying the indigenous forest as part of the forest under the state ownership and the intention to exploit the forest for the prosperity of the whole people or at this context for the majority of the people is declared to be unconstitutional by the Court as and contradict to Article 1(3), Article 18 B (2), Article 28 D (1) and Article 28I (3) the UUDNRI 1945. The Court said that Article 1 (6) of the Forestry Law, which stipulates that the recognition to the indigenous forest as part of the forest under the management of the state would have impact of neglecting the rights of ethnic-indigenous community.

To this extent, the Court Decision indicates that the Court came up as bridging the gap between the Legislative and the President and the people by determining that a norm has a character of conditional constitutional. According to the Court decision, the Forestry Law has to be understood imperatively that the government when determining the forest area is required to involve the participation from people as a control for government in order to make sure the fulfilment of the constitutional rights and in order to ensure that the 
majority and minority of the people are living in prosperity and gaining access to a healthy environment as well as getting their property rights which shall not be reduced by anyone else. In this context, the Court refers to Article $28 \mathrm{H}$ Section (1) and Section (4) of the UUD NRI 1945. In general, the Court shows the commitment and effort to uphold the constitutional value of the recognition of the ethnic-indigenous community as well as the commitment to protect democracy value on accommodating and respecting the minority rights. The Court shows its consistent stance in defending its independency by referring to the Constitution. It declared that the Constitution is ensuring the recognition and constitutional existence of the ethnic-indigenous community as well as its traditional-indigenous "ulayat" rights as long as it is still alive and according to the society and the principle of unitary Republic of Indonesia as it is stipulated in Article 18 B Section (2) of the UUD NRI 1945. The Court also defended the minority ethnic indigenous rights of the ethnic indigenous community against the eviction and from the elite-populist interest, which means that the Court has protected constitutional democracy values. This is also in order to protect the cultural identity and the traditional indigenous ulayat rights from any threats of tyranny majority.

In general remarks, the Court's Decision shows that the Constitutional Court decided the case by defending minority against the majority. It defended the existence and ulayat rights of the minority-ethnic-indigenous community against the extinction and tyranny of the majority. The Court also shows the tendency of being impartial and independence instead of showing the tendency of judicial populism. It, in fact, shows the commitment of protecting minority from any kind of elite-populist interest, such as the interest of the domination of natural resources by state for the public purpose.

On the Court's landmark decision of the educational rights, the fulfilment of the economic, social rights may describe how the Court could avoid judicial populism and preserve the constitutional and the rule of law principles. However, the Court's Decision may show the tendency of being protective of democracy and the rule of law. However, it may slightly speak as what the interest of the 
majority will of the people. The Court Decision No. 13/PUU-VI/2008 on the Judicial Review of Law No. 16/2008 on the State Budget decided that the state obligation to provide education budget for the fulfilment of the education rights has the character of immediate. It has the meaning that the Court with majority in favour affirmed that in the fulfilment of the education rights, State has an immediate obligation to provide and allocate budget for education according to the Constitution. This Court's Decision actually shows the tendency of being populist but still in the corridor of accommodating the minority by making priority to access education in the form of providing free education for majority and minority of the people. At this context, the Court decided that the Constitution is literally requiring $20 \%$ budget from APBN to be allocated to the fulfilment of education rights. In theory, the education rights are in the regime of economic, social, and cultural with the characteristic of being aspiration and progressively realization.

The Court affirmed that the method of the educational budget calculation determined by the government. However, the Court assumed that the method is not a method which is intended by the Constitution and not the rightly method to allocate the percentages of educational budget in Law APBN-P 2008. The Court strictly argued that the method has to be strictly in accordance to the Constitution, and that, any other basis method to calculate the educational budget is unconstitutional and shall be put aside. The Court declared that the use of any method for allocating educational budget by the government would not eliminate any interest groups to invoke their constitutional rights in case there is potential or factual injury caused by the government method. To this extent, the Court gives room for the government to use any other methods which are beyond the constitutional method as well as giving opportunity to any groups to invoke their constitutional rights. ${ }^{35}$

In general, the Court strongly affirms to uphold the constitutional norms which make a priority to the $20 \%$ educational budget allocation from the state

35 Judicial Review of Law No. 16/2008 on the State Budget. Case Number 13/PUU-VI/2008. The Constitutional Court of the Republic of Indonesia. 
budget and from the local government budget. The Court emphasizes that the $20 \%$ allocation budget for education is a constitutional obligation which put obligation for the government to stick with the percentages in the Constitution. ${ }^{6}$ Therefore, the Court decided on the basis of upholding the rule of law and constitutional democracy principle in the Constitution that the fulfilment of the education rights has to be in accordance with the Constitution. In order to anticipate the negligence of the rule of law principles, the Court reminds the legislative and executive branch as well as giving guidance to the local government to allocate $20 \%$ state budget and local government budget for the fulfilment of education rights. At this context, the Court was about abiding and being counterpart of the legislative and the executive. The Court assumes that the method of budget allocation used by the government and the legislative may have been adjusted with the situation and condition also according to the demand of the people but does not in accordance to the Constitution. Therefore, the Court assumed that the policy of budget allocation for education which was legalized in the UU APBN-P 2008 was unconstitutional since it was only $15.6 \%$ and not $20 \%$ as required by the Constitution. The decision shows that the Court had defended the principles laid down in the Constitution and ordered the legislative and the executive to strictly fulfill the education rights by allocating $20 \%$ state budget for the educational budget.

Both landmark Decisions were taken by majority in favour by the Constitutional judges. The Court's decision shows that the MKRI, in particular area of economic and social rights, which in this paper is addressed to the minorityethnic-indigenous rights or marginalized economic and social rights for access to traditional forest to fulfil their economic rights and the education rights for all the people, had given respects and protection to the Constitutional values, and had decided of what it has to be decided according to the Constitution. The Court has proved that it had defended its independence by not deciding of what it was to be demanded by the public. The court shows that its decision is not affected by the majority pressures. The Court also had shown its impartiality 
as a bridge between the others branches and tend to put forward the justice and the rule of law while putting aside judicial populism. The Court may be an institution to perform check and balances and prevent any populist policy produced by the populist government, which may make a priority to majoritarian people will, but on the other hand, may push away the minority. In its decision of education budget, the Court shows its attitude of defending its independency while performing its function of check and balances against other branches. The Court is about override of being judicial populism by protecting the Constitution, democracy, and the rule of law in Indonesia. The Court has shown its attitude to deliver its transformative decisions by setting considerable remedial in the decision on educational state budget. Its commitment to implement what is in accordance with the Constitution is shown in the decision of affirming the recognition to the marginalized groups as well as affirming their Ulayat rights as in accordance with the Constitution values in respecting the indigenous minority groups in Indonesia. Both decisions are indicating that the MKRI does not about gaining political support but make small improvement by giving advice to the executive and legislative in terms of allocation method for the fulfilment of educational rights.

\section{CONCLUSION}

The Constitutional Court has the role to maintain the improvement process balance with the constitutional democracy principles. While the rule of law is the basis of democracy, it is an effective instrument promoting responsibility, accountability, reciprocity, and trust in the effort to accommodate the interest of majority and minority. Within the rule of law framework, the Constitutional Court shall integrate judicial independence and protect constitutional democracy values in its judicial decision making.

The Court has the role to be an effective catalyst to resist populism in the judicial decision making by setting the democracy standards, such as cultural identity, pluralism values, religion, human rights, economic prosperity, ethnicity, citizenship, the judicial independence, and system of government which in line 
with the effort to protect the economic and social rights. Those standards could resist populist politics that are mainly based on the division and rules. In this context, the Court shall put forward the judicial independence and put aside for being judicial populist. The Court shall involve in grassroots organizing and helping people to understand democracy and the rule of law by its judicial decision as a counter-act of populist policies, and form alternative polices to counteract the development of economic and social rights. Hence there is a continued role for the Constitutional Court to provide legal certainty for the protection of economic and social rights.

The Constitutional Court, as the legal institution holding judiciary powers, shall prove to make function the Laws properly in the implementation of economic and social rights protection. As the institution bridging the elite government and the people, the Court has to provide more opportunities and mechanisms for minorities to express their will. As the stabilizer and equalizer, the Court has an important role since the fact that between constitutional democracy and populism are coincide and have to be reconciled. In this context, the Court has to ensure that the minority interests are accommodated in all aspects of the state.

The Court facilitates effective control to the parliament, which representing the majority of people will and the government branch, which has the power to make laws. The Indonesian Constitution has provided facilitation of the effective control by setting the mechanism of checks and balances. Both analyzed Court's Decisions set down the landmark of the Court's Decision on the effort of protecting the economic and social rights as well as upholding democracy and the rule of law. The Indonesian Constitutional Court has shown a tendency to keep away from judicial populism by putting forward the judicial independence. In line with the Constitution, the Court has the effort to hold up populism. The Court shows its legitimacy and independence to make sure everything has already in line with the Constitution and the Laws.

Populism may trigger the emergence of judicial populism when the Court put forward the people will while putting aside the judicial independence and impartiality. In this context, such tendency is what we may call as judicial 
populism. Judicial populism may be envisaged from how the judge tends to speak for the people or when the Court delivers decision adjusted and influenced by the majority of the people will while it is actually beyond justice, impartiality, and judicial independence. From both the Court's landmark Decisions discussed in this paper, it shows that the MKRI, in particular area of educational rights and ulayat rights, which in this paper is addressed to the minority-ethnicindigenous rights for access to traditional forest to fulfil their economic rights and the education rights for all the people, had given respects and protection to the Constitutional values, and had decided of what it has to be decided according to the Constitution. The Court has proved that it had maintained its independence by not deciding of what it was to be demanded by public.

\section{BIBILIOGRAPHY}

Alon, Harel. "Courts in a Populist World." VerfBlog, 27 April 2017. https:// verfassungsblog.de/courts-in-a-populist-world/. DOI: https://dx.doi. org/10.17176/20170428-104853.

Basic Principles on the Independence of the Judiciary Adopted by the Seventh United Nations

Congress on the Prevention of Crime and the Treatment of Offenders held at Milan from 26 August to 6 September 1985 and endorsed by General Assembly resolutions 40/32 of 29 November 1985 and 40/146 of 13 December 1985.

Daintith, Terence. "The Constitutional Protection of Economic Rights." I.CON 2, no. 1 (2004).

Eby Hara, Abubakar. "Populism in Indonesia and its Threats to Democracy." Advances in Social Science, Education and Humanities Research (ASSEHR) 129 (2018).

Fournier, Théo. "From Rhetoric to Action - A Constitutional Analysis of Populism." EUI Working Paper LAW 2018/o8, European University Institute, 2017. 
Jacome, Jorge Gonzales. "In Defense of Judicial Populism: lessons from Colombia." Int'l J. Const. L,( 3 May 2017). http://www.iconnectblog.com/2017/05/indefense-of-judicial-populism-lessons-from-colombia/

Kimura, Ehito. "Populist Politic in Indonesia." Asia Pacific Bulletin No. 407, East- West Center, 7 December 2007.

Kureshi, Yasser. "What is Judicial Populism and how does it Work in Pakistan?" www.dawn.com/news/1461194/what-is-judicial-populism-and-how-does-itwork-in-pakistan.

Landau, David. “The Reality of Social Rights Enforcement.” Harvard International Law Journal 53, no. 1 (2012).

Liano, Arjana. "Independence of the Judiciary."Juridical Tribune 3, no. 2 (2013): 109 - 115. http://tribunajuridica.eu/arhiva/An3v2/7\%2oLlano.pdf.

Mietzner, Marcus. "Indonesia's 2009 Elections: Populism, Dynasties and the Consolidation of the Party System." Lowy Institute for International Policy (2009).

Mietzner, Marcus. "Reinventing Asian Populism: Jokowi’s Rise, Democracy, and Political Contestation in Indonesia." Policy Studies 72 (2015).

Miller, Kenneth P. "Symposium Constraining Populism: The Real Challenge of Initiative Reform." 41 Santa Clara Law Review 1037 (2001).

Mudde, Cas. "The Populist Zeitgeist." Government and Opposition 39, no. 4 (2014).

Nikku, Bala Raju Nikku and Azman, Azlinda. "Populism in the Asia: What Role for Asian Social Work?" Social Dialogue, September 17, 2017.

Plato. “The Republic." http://www.idph.net.

Polybius. The History of Polybius Book Six, in Parentheses Publication Greek Series. Translated by Evelyn S. Shuckburgh. Cambridge, Ontario, 2012.

Pratikno and Cornelis Lay. "From Populism to Democratic Polity: Problems and Challenges in Surakarta Indonesia." PCD Journal III, no. 1-2 (2011). 
Rooduijn, Matthijs. "A Populist Zeitgeist?: The Impact of Populism on Parties Media and the Public in Western Europe." Dissertation, University van Amsterdam, 2013.

Rousseau, Jean-Jacques. Social Contract. Translated by Jonathan Bennett, 2017. www.earlymoderntexts.com.

Savitri, Laksmi Adriani and Devi Adriyati. "The Demise of Emancipatory Peasant Politics? Indonesian Fascism and The Rise of Islamic Populism." ERPI 2018 International Conference Paper, International Institute of Social Studies (ISS) Coin The Hague, Netherlands, 17-18 March 2018 .

Törnquist, Olle. "Stagnation or Transformation in Indonesia?" Economic and Political Weekly XXIIX, no. 50 (13 December 2014).

Walker, Neil. "Populism and Constitutional Tension." Jean Monnet Working Paper 15/17, Symposium: Public Law and The New Populism, 2017. 